\title{
Differential recognition of ITSN2/Ese2 by the SH2 domains of Fyn, Abl1, PLCg1 and PI3KR1 in mouse tissues
}

\author{
O. V. Novokhatska, S. V. Pankivskyy, M. V. Dergai, L. O. Tsyba, A. V. Rynditch
}

State Key Laboratory of Molecular and Cellular Biology,

Institute of Molecular Biology and Genetics, NAS of Ukraine

150, Akademika Zabolotnogo Str., Kyiv, Ukraine, 03680

olga.novokhatska@gmail.com

\begin{abstract}
Phosphorylation of endocytic adaptor ITSN2 that enabled its interaction with the SH2 domains of signaling proteins was recently reported. The aim of this study was to determine whether tissue-specific ITSN2 phosphorylation and subsequent recognition by phosphotyrosine-binding domains could occur in mouse tissues. Methods. In silico prediction of interaction motifs, expression of recombinant proteins in bacterial system, GST pull-down analysis, immunoblotting. Results. Analysis of phosphoproteomic data demonstrated tyrosine phosphorylation of mouse ITSN2 homologue, Ese2 protein. Scansite service was used to predict binding motifs for the SH2 domains of Fyn, Abl1, PLCg1 and PI3KR1 within Ese2. Comparison of ITSN2 and Ese2 sequences showed conservation of predicted interaction motifs between human and mouse. GST-fused SH2 domains of Fyn, Abll, PLCg1 and PI3KRI were obtained and used as phosphorylation "sensors» of tyrosine-based motifs within Ese 2 molecule. Binding of Ese 2 to the SH2 domains of Fyn and PLCg1 was observed in brain, lung and heart whereas SH2 domains of Abl1 and PI3KR1 interacted with Ese2 in lung and heart only. Conclusions. Differential Ese2/ SH2 interactions in tissues suggest that tissue-specific tyrosine phosphorylation might regulate specific binding of the Ese2 adaptor to the signaling molecules.
\end{abstract}

Keywords: ITSN2/Ese2, tyrosine phosphorylation, SH2 domain, tissue-specific interactions.

Introduction. Intersectin 1 and 2, ITSN1 and ITSN2, are endocytic adaptors that mediate assembly of multiprotein complexes during clathrin-mediated endocytosis. Both proteins have the same domain composition and are widely expressed in tissues (reviewed in [1,2]). Recently we performed functional comparison of ITSNs and showed that ITSN2 is tyrosine phosphorylated in contrast to ITSN1. Phosphorylated form of ITSN2 was recognized by the $\mathrm{SH} 2$ domains of signaling proteins in HeLa cells [3]. According to the phosphoproteomic data and in silico prediction, nine tyrosine residues of ITSN2 can be modified and each recognized by several partners $[4,5]$. We suggest that in tissues, modification of different residues could allow binding of distinct pro-

(C) Institute of Molecular Biology and Genetics, NAS of Ukraine, 2013 tein partners. The aim of this study was to verify this hypothesis using mouse model.

Materials and methods. In silico prediction of binding motifs for $\mathrm{SH} 2$ domains was performed using Scansite service [4].

Expression constructs and antibodies. The GSTSH2 domains of Fyn, PLCg1, Abl1 and PI3KR1 were described previously [3]. Polyclonal antibodies against the CCR of ITSN2 were produced in rabbits immunized with the recombinant His-tagged protein comprising amino acid residues 349-499 of ITSN2.

Binding assays and Western blot analysis. The recombinant GST-fused proteins were expressed in Escherichia coli and affinity purified using Sepharose 4B («GE Healthcare», USA) according to the manufactu rer's instructions. Lysates of mouse tissues were prepa- 


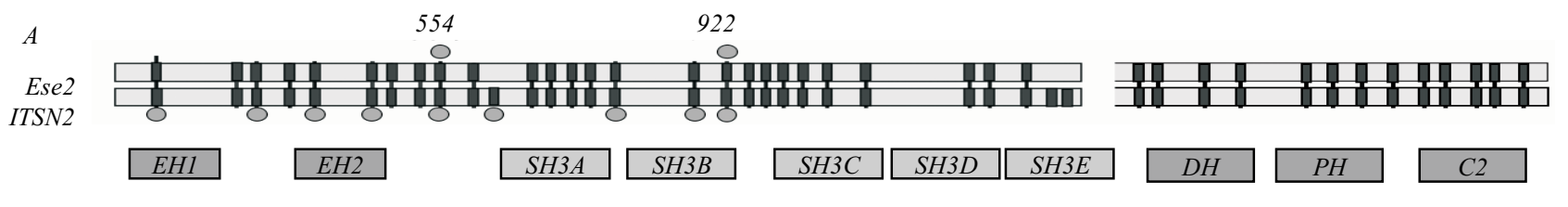

Short isoform

Long isoform C-terminal extension

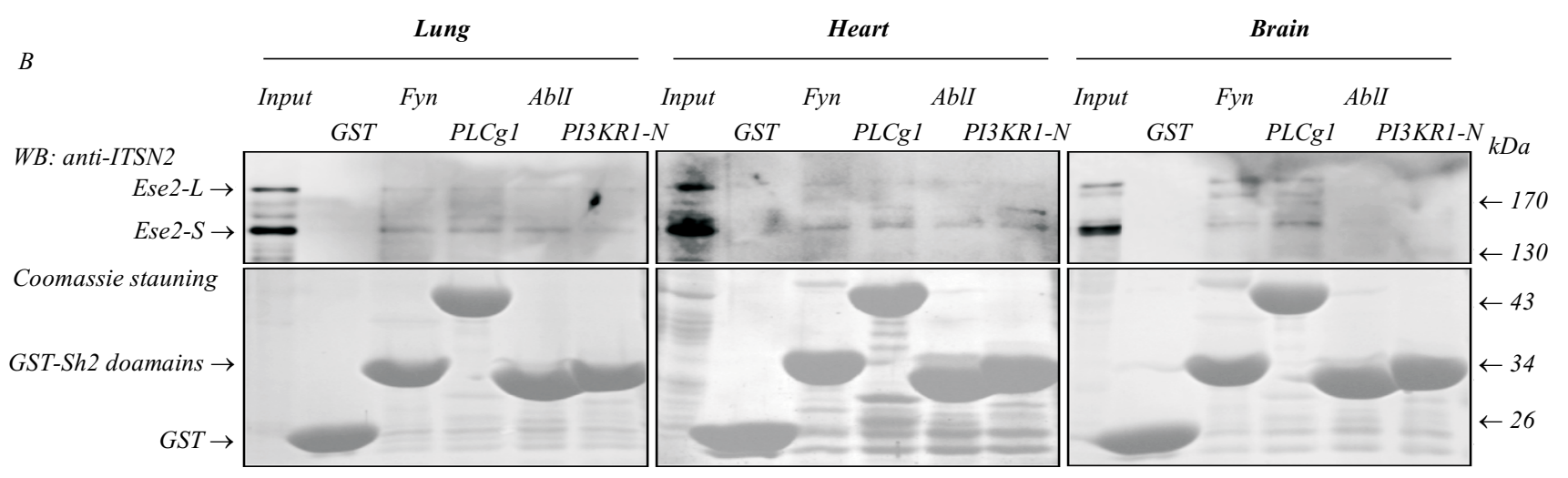

Ese2 is differentially recognized by various SH2 domains in mouse brain, lung and heart: $A$ - schematic representation of ITSN2/Ese2 domain organization and distribution of tyrosine residues (shown as black boxes). Tyrosine residues that are phosphorylated according to phosphoproteomic data are indicated by circles. The number above each circle indicates the position of the residue within Ese 2 protein; $B$ - Bacterially expressed and affinity purified GST-SH2 domains of Fyn, Abl1, PI3KR1, PLCg1 or GST alone (control) were bound to glutathione beads and used as bait to pull down Ese2. For in vitro binding assays GST-fused proteins were incubated with lysates of mouse brain, heart and lung. Bound proteins were analyzed by Western blotting using antibodies against ITSN2. GST-fused proteins were visualized by Coomassie staining. PI3KR1-N corresponds to the N-terminal SH2 domain of PI3KR1. Ese2-S/L, short/long isoform of Ese2; WB, Western blotting

red in extraction buffer containing $20 \mathrm{mM}$ Tris- $\mathrm{HCl}$, $\mathrm{pH} 7.5,0.5 \% \mathrm{NP} 40,150 \mathrm{mM} \mathrm{NaCl}, 10 \%$ glycerol, $1 \mathrm{mM} \mathrm{Na}_{3} \mathrm{VO}_{4}$ and protease inhibitor cocktail («Roche», France). For pull-down assays, immobilized on beads GST-SH2 domains were incubated with cell lysates for $1 \mathrm{~h}$ at $4{ }^{\circ} \mathrm{C}$. The beads were then washed with extraction buffer three times at $4{ }^{\circ} \mathrm{C}$ and boiled in Laemmli buffer (150 mM Tris-HCl, pH 6.8, $2.5 \%$ glycerol, $10 \%$ SDS, $3 \% \beta$-mercaptoethanol and $0.5 \%$ bromophenol blue).

Proteins were resolved in SDS-PAGE, transferred to nitrocellulose membranes («Bio-Rad», USA) and probed with appropriate antibodies for $1 \mathrm{~h}$ at room temperature. Detection was performed using ECL reagents. Chemiluminescence was captured with Molecular Imager ChemiDocTM XRS+ («Bio-Rad»).

Results and discussion. To verify our hypothesis about the existence of ITSN2 tissue-specific phosphorylation/interaction pattern, mouse tissues were used. The similarity between human ITSN2 and homologous mouse Ese 2 protein is $92 \%$. Therefore we used previously obtained anti-ITSN2 antibodies [3] that were able to detect major short and long Ese2 isoforms in mouse tissue lysates. We tested binding of $\mathrm{SH} 2$ domains of Fyn and Abll kinases as well as phospholipase $\mathrm{C}$ gamma 1 (PLCg1) and regulatory subunit of PI3K (PI3KR1) to Ese2 from mouse tissues.

Using Scansite service the binding motifs for these SH2 domains were predicted within Ese2 sequence (Table). Phosphorylation of Y554 and Y922 of Ese2 protein was demonstrated by phosphoproteomic studies (Figure, $A$ ) [5].

For all proteins except for Fyn kinase conserved between human and mouse tyrosine-based interaction motifs were predicted within Ese2.

Affinity purified GST-SH2 domains of Fyn, PLCg1, Abl1 and PI3KR1 were used to pull down Ese2 from mouse brain, lung and heart lysates. In mouse lung and heart lysates Ese2 was recognized by all tested $\mathrm{SH} 2$ domains (Figure, $B$, left and middle panels). Only the $\mathrm{SH} 2$ domains of Fyn and PLCg1 were able to pull down Ese 2 from mouse brain lysate (Figure, $B$, right panel).

Obtained data indicate that in various tissues phosphorylation of distinct tyrosine residues within ITSN2 
Ese2 tyrosine residues within predicted SH2-binding motifs

\begin{tabular}{|c|c|c|c|}
\hline Fyn & PLCg1 & Abl1 & PI3KR1 \\
\hline- & - & - & Y39 \\
\hline- & - & - & Y194 \\
\hline- & Y554 & Y554 & - \\
\hline- & Y931 & - & - \\
\hline Y949 & - & - & - \\
\hline- & Y974 & - & - \\
\hline- & Y1021 & Y1021 & Y1124 \\
\hline- & - & - & Y1168 \\
\hline- & - & - & Y1212 \\
\hline- & - & - & Y1534 \\
\hline Y1584 & - & - & - \\
\hline
\end{tabular}

could occur and demonstrate recognition of ITSN2 by particular SH2-containing proteins in a tissue-specific manner. Recent studies focused on investigation of tissue-specific phosphorylation of proteins in mouse tissues indicated that mainly phosphoproteins are widely expressed [6].

It was suggested that tissue-dependent phosphorylation serves for regulation of ubiquitous proteins and tissue-specific phenotypes are achieved by ubiquitous pathways. Expression of ITSN2 major isoforms, short and long, was demonstrated in many human and mouse tissues $[1,2]$. The role of ITSN2 in various cell-specific processes such as induction of $\mathrm{T}$ cell receptor endocytosis, formation of lumen during epithelial morphogenesis, regulation of actin cytoskeleton dynamics during gastrulation and caveolae endocytosis in endothelial cells is established [7-10].

The discovered tissue-dependent recognition of ITSN2 by the $\mathrm{SH} 2$ domains of signaling proteins could contribute to ITSN2 function in reported or not yet studied cell type-specific processes.

Acknowledgments. We thank Dr. Larysa Macewicz for providing mouse tissues. This work was partially supported by target complex interdisciplinary program of scientific researches of NAS of Ukraine «Fundamentals of molecular and cell biotechnologies».
О. В. Новохачька, С. В. Паньківський, М. В. Дергай, Л. О. Циба, А. В. Риндич

Диференційне впізнавання білка ITSN2/Ese2 доменами SH2 білків Fyn, Abl1, PLCg1 i PI3KR1 у тканинах миші Резюме

Нещодавно виявлено фосфорилювання адаптора ендоцитозу ITSN2, що забезпечуе впізнавання иього білка SH2-доменами білків, залучених до передачі мітогенного сигналу. Метою иієїроботи було перевірити, чи має взаємодія ITSN2 з SH2-вмісними білками тканиноспецифічний характер. Методи. Передбачення мотивів взаємодії іп silico, експресія білків у бактерійній системі та культурі клітин ссавиів, преципітація з використанням білків, злитих з GST. Результати. Дані фосфопротеомних досліджень свідчать про фосфорилювання тирозинових залишків гомолога ITSN2 миші, білка Ese2. За допомогою сервісу Scansite у складі Ese2 передбачено мотиви взаємодії з доменами SH2 білків Fyn, Abll, PLCg1 i PI3KR1. Порівняння послідовностей інтерсектинів людини та миші показало консервативність передбачених мотивів. Отримано злиті з GST домени SH2 білків Fyn, Abll, PLCg1 i PI3KR1, які використано для прецииітаиії білка Ese2 з лізатів мозкy, легень і серия миті. Зв 'язування Еsе2 з доменами SH2 білків Fуn i PLCg1 спостерігали в усіх досліджуваних тканинах, тоді як домени SH2 білків Abl1 і PI3KR1 упізнавали Ese2 лише в легенях та сериі. Висновки. Диферениійне впізнавання Ese2/SH2 у тканинах дозволяє припустити, щзо тканиноспеиифічне фосфорилювання регулює специфічне зв 'язування адапторного білка Ese2 із сигнальними молекулами.

Ключові слова: ITSN2/Ese2, фосфорилювання тирозинових залишків, домен SH2, тканиноспецифічні взаємодії.

\section{О. В. Новохаикая, С. В. Паньковский, Н. В. Дергай, Л. А. Цыба, A. В. Рындич}

Дифференциальное узнавание белка ITSN2/Ese2 доменами SH2 белков Fyn, Abl1, PLCg1 и PI3KR1 в тканях мыши

Резюме

Недавно показано фосфорилирование адаптора эндочитоза ITSN2, опосредуюшее узнавание этого белка SH2-доменами белков, вовлеченных в передачу митогенного сигнала. Целью этой работы было проверить, имеет ли взаимодействие ITSN2 c SH2содержащими белками тканеспецифический характер. Методы. Предсказание мотивов взаимодействия in silico, экспрессия белков в бактериальной системе и культуре клеток млекопитающих, преципитация с использованием белков, слитых с GST.Peзультаты. Данные фосфопротеомных исследований свидетельствуют о фосфорилировании тирозиновых остатков гомолога ITSN2 мыши, белка Ese2. При помощи сервиса Scansite в составе Ese2 предсказано мотивы взаимодействия с доменами SH2 белков Fyn, Abl1, PLCg1 и PI3KR1. Сравнение последовательностей интерсектинов человека и мыши показало консервативность предсказанных мотивов. Получены слитые с GST домены SH2 белков Fyn, Abl1, PLCg1 и PI3KR1, использованных для преципитации белка Esе2 из лизатов головного мозга, легких и сердиа мыши. Связывание Ese2 с доменами SH2 белков Fyn и PLCg1 наблюдали во всех исследованных тканях, тогда как домены SH2 белков Abl1 и PI3KR1 узнавали Еsе2 только в тканях легких и сердия. Выводы. Дифференциальное узнавание Ese2/SH2 в тканях позволяет предположить, что тканеспецифическое фосфорилирование опосре- 
дует специфическое связывание адаптерного белка Ese2 с сигнальными молекулами.

Ключевые слова: ITSN2/Ese2, фосфорилирование тирозиновых остатков, домен SH2, тканеспецифические взаимодействия.

\section{REFERENCES}

1. Tsyba L., Nikolaienko O., Dergai O., Dergai M., Novokhatska O., Skrypkina I., Rynditch A. Intersectin multidomain adaptor proteins: regulation of functional diversity // Gene.-2011.-473, N 2.-P. 67-75.

2. Tsyba L. O., Dergai M. V., Skrypkina I. Ya., Nikolaienko O. V., Dergai O. V., Kropyvko S. V., Novokhatska O. V., Morderer D. Ye., Gryaznova T. A., Gubar O. S., Rynditch A. V. ITSN protein family: regulation of diversity, role in signalling and pathology // Biopolym. Cell.-2013.-29, N 3.-P. 244-251.

3. Novokhatska O., Dergai M., Tsyba L., Skrypkina I., Filonenko V., Moreau J., Rynditch A. Adaptor proteins Intersectin 1 and 2 bind similar proline-rich ligands but are differentially recognized by SH2 domain-containing proteins // PLoS One.-2013.-8, N 7.e70546.

4. Obenauer J. C., Cantley L. C., Yaffe M. B. Scansite 2.0: Proteome-wide prediction of cell signaling interactions using short sequence motifs // Nucleic Acids Res.-2003.-31, N 13.-P. 36353641 .

5. Hornbeck P. V., Kornhauser J. M., Tkachev S., Zhang B., Skrzypek E., Murray B., Latham V., Sullivan M. PhosphoSitePlus: a comprehensive resource for investigating the structure and func- tion of experimentally determined post-translational modifications in man and mouse // Nucleic Acids Res.-2012.-40, Database issue.-D261-270.

6. Huttlin E. L., Jedrychowski M. P., Elias J. E., Goswami T., Rad R., Beausoleil S. A., Villen J., Haas W., Sowa M. E., Gygi S. P. A tissue-specific atlas of mouse protein phosphorylation and expression // Cell.-2010.-143, N 7.-P. 1174-1189.

7. McGavin M., Badour K., Hardy L. A., Kubiseski T. J., Zhang J., Siminovitch K. A. The intersectin 2 adaptor links Wiskott Aldrich syndrome protein (WASp)-mediated actin polymerization to T cell antigen receptor endocytosis // J. Exp. Med.-2003.-194, N 12.-P. 1777-1787.

8. Rodriguez-Fraticelli A. E., Vergarajauregui S., Eastburn D. J., Datta A., Alonso M. A., Mostov K., Martin-Belmonte F. The $\mathrm{Cdc} 42 \mathrm{GEF}$ Intersectin 2 controls mitotic spindle orientation to form the lumen during epithelial morphogenesis // J. Cell Biol.2010.-189, N 4.-P. 725-738.

9. Novokhatska O., Dergai M., Houssin N., Tsyba L., Moreau J., Rynditch $A$. Intersectin 2 nucleotide exchange factor regulates Cdc42 activity during Xenopus early development // Biochem. Biophys. Res. Commun.-2011.-408, N 4.-P. 663-668.

10. Klein I. K., Predescu D. N., Sharma T., Knezevic I., Malik A. B., Predescu $S$. Intersectin-2L regulates caveola endocytosis secondary to Cdc42-mediated actin polymerization // J. Biol. Chem.2009.-284, N 38.-P. 25953-25961. 